The BDJ News section accepts items that include general news, latest research and diary events that interest our readers. Press releases or articles may be edited, and should include a colour photograph if possible. Please direct your correspondence to the News Editor, Arveen Bajaj at the BDJ, 64 Wimpole Street WIG 8YS or by e-mail to bdj@bda.org

\section{Education appointment}

Elizabeth Davenport has been promoted to Professor of Dental Education at Barts and The London Queen Mary's School of Medicine and Dentistry.

An editorial board member for the $B D J$, professor Davenport qualified BDS from the Royal Dental Hospital of London School of Dental Surgery in 1974.

She has been committed to a career in paediatric dentistry having spent two years gaining a wider experience in hospital, community and general practice. She was appointed lecturer in child dental health at the London Hospital Medical College Dental School in 1980. She obtained her PhD and also completed an MSc in epidemiology at the London School of Hygiene and Tropical Medicine in 1993 and was awarded FDS RCS Ed without examination in 2003.

Her research interests are centred on the delivery of education and most especially assessment issues, and the outcome of periodontal disease in women of child bearing age.

Educational research has resulted in the development of a Progress File Learning System for use by undergraduate dental and PCD students and their tutors.

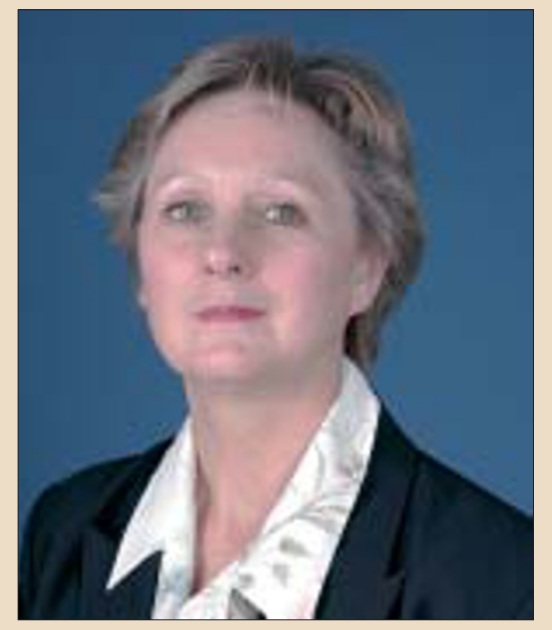

\title{
Drugs detox centre opens dental suite
}

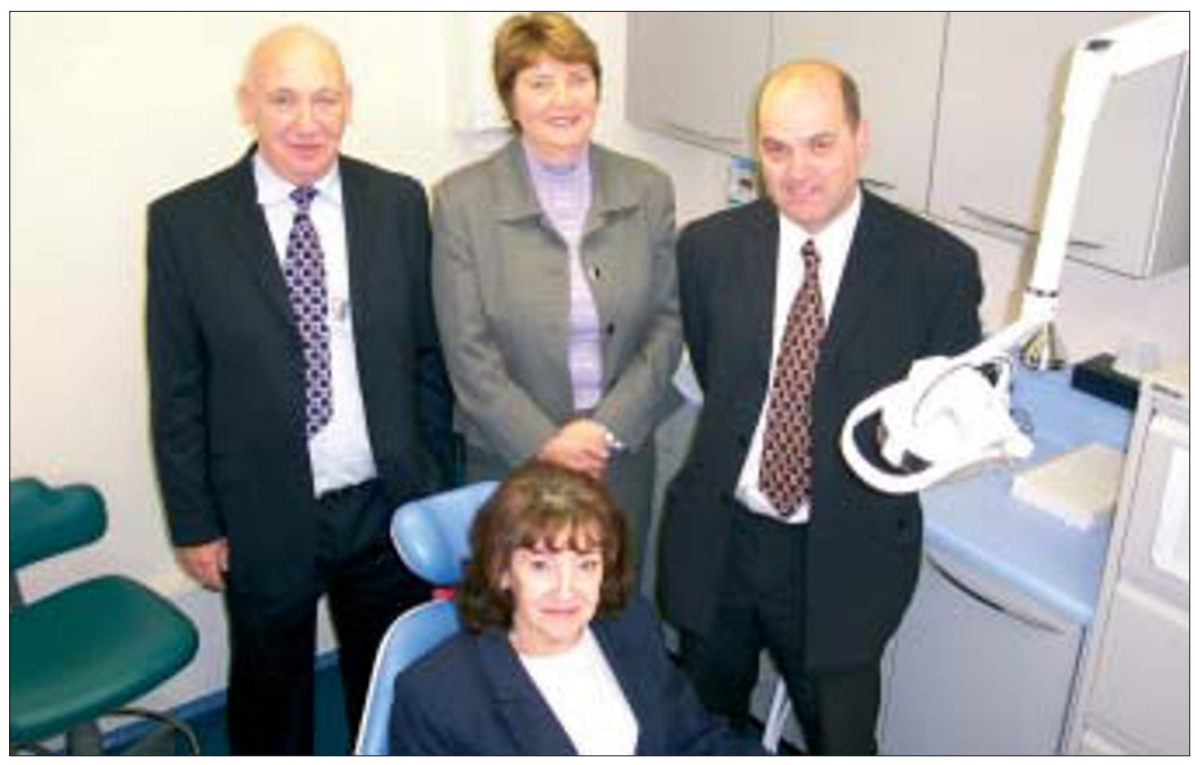

The Gateway Centre, a community based NHS drugs detox unit in Liverpool city centre recently opened its new $€ 30,000$ dental suite. The centre's health team discovered that many drug users were left with serious dental problems as a consequence of their addiction. The service is part of an $€ 11$ million annual investment in dentistry in Liverpool, operated by nearly 200 dentists. Pictured above: Taking the chair is chairwoman of North Liverpool Primary Care Trust, Lillian Hopkins, with (from left to right back row): Joe Holman, Gateway Centre manager, Maxine Collins, dental promotion officer, and Mark Hopkins, clinical director of drugs and alcohol services, for Mersey Care NHS Trust.

\section{Disability legislation to affect dentists}

By 1st October, 2004, every business, large or small from dentist's surgeries to local shops will need to become more user-friendly to Britain's 8.6 million disabled people in order to adhere to legislation introduced under the Disability Discrimination Act.

Over two million British businesses will be affected by the legislation, and will need to make changes such as adapting premises, removing physical barriers or providing services another way to ensure disabled people can use them.

The Disability Rights Commission (DRC) has recently launched its Open4All campaign to help businesses understand the new legislation and aims to provide practical advice and information to those affected by the changes.

Recent research into access to health services conducted by the organisation

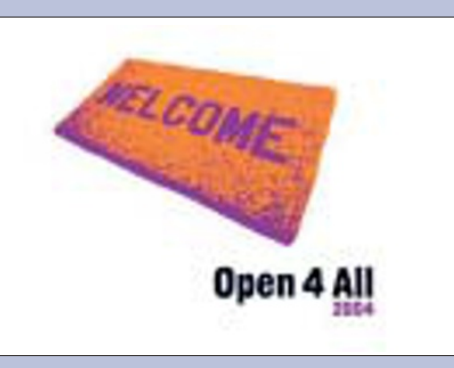

found that 41 per cent of disabled people reported problems using a dentist, hospital or GP.

When asked to name the two biggest obstacles faced, the survey found that 45 per cent said the steps to a building were problematic and 39 per cent said being unable to use disabled parking spaces presented a difficulty.

According to the DRC, failure to act could result in legal action. For more information visit www.open4all.org. 


\section{DIARY}

November 2003

National Association of Dental Advisers

Conference 2003

Date: 20-21.11.03

Venue: Jurys Bristol Hotel

Contact: Events Office,

British Dental Association

Tel: +44 (0) 2075634590

Fax: +44 (0) 2075634591

E-mail: events@bda.org

SAAD: Advanced Conscious Sedation - The way forward

Date: 29.11.03

Venue: GDC, London

Contact: SAAD conference

administration

Tel: +44 (0) 2079351656

March 2004

2nd Asia Pacific Congress on Craniofacial

Distraction Osteogenesis

Date: 5-10.03.04

Venue: Maldives

Contact: www.distraction2004.com

E-mail: secretary@distraction2004.com

May 2004

BDA National Annual Conference

Date: 06.05.04 - 08-05.04

Contact: Events Office,

British Dental Association

Venue: Bournemouth International

Centre

Tel: +44 (0) 2075634590

Fax: +44 (0) 2075634591

E-mail: events@bda.org

\section{Dentistry with a difference}

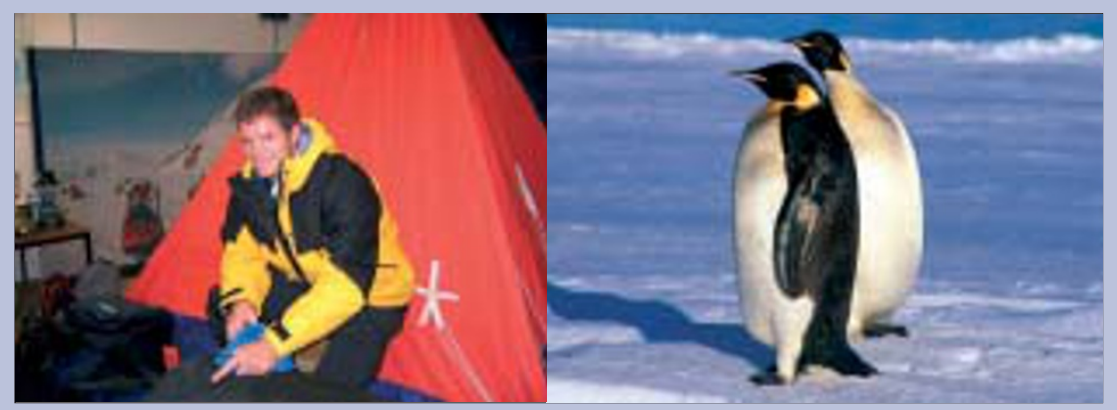

The British Antarctic Survey (BAS) has appointed Ben Molyneux as its new dental surgeon for the 2003/2004 season.

During his ten month appointment, he will sail from UK to the Antarctic on the Royal Research Ship Ernest Shackleton in October to tour the British Antarctic bases during the austral sum- mer. The BAS dental surgeon is responsible for carrying out a rigorous screening, treatment and preventive programme for personnel prior to the ship's departure and for setting up and equipping the dental surgery on board.

Ben Molyneux takes over the post from Penny Granger who spent two years as a dentist for the BAS.

\section{FDI president outlines goals}

Dr. Heung-Ryul Yoon was elected President of the FDI World Dental Federation at its recent annual conference in Sydney.

In his acceptance speech, Dr. Yoon outlined the goals he intended to focus on during his term of office.

He stated that these were to finalise the governance review with all the necessary constitutional amendments, to increase the quality and quantity of FDI statements and to increase the FDI's non-dues income to strengthen its financial position.

He added that special emphasis should be put on the world's developing countries and at the same time enhance the cooperation with the WHO.

He also stated that the FDI should enhance the image and reputation of our profession by fully utilising international mass media.

Currently, 152 National Dental Associations, 35 International Dental Associations representing more than 700,000 individual dentists are members of the FDI.

The next world conference is to be held in New Delhi in 2004. For more information visit www.fdiworldental.org or e-mail info@fdiworldental.org. 


\section{Mercy mission}

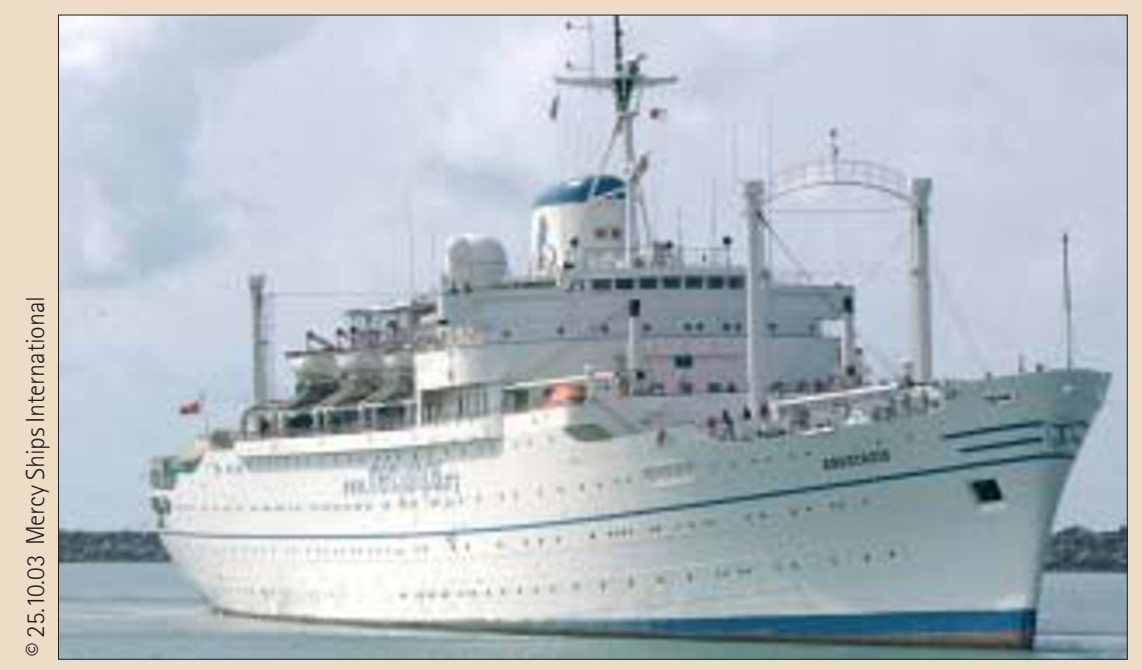

The world's largest private hospital ship Mercy Ships M/V Anastasis has recently set off for Sierra Leone after docking in Sunderland in the UK to pick up volunteers and supplies for its next voyage.

The Anastasis is one of three vessels belonging to Mercy Ships, an international charity founded on a Christian ethos, now in its 25th year, which takes medical aid and development assistance to poor and developing nations.

The fleet consists of the M/V Caribbean Mercy, the M/V Africa Mercy and the flagship, M/V Anastasis. With a dental team on board all the time, the Anastasis is staffed with an all-volunteer crew of 350 including doctors, nurses, surgeons as well as back up teams of ancillary staff some who have spent years on board the vessel.

On its most recent trip, also to Sierra Leone, the ship's dental team set up dental clinics in villages and treated 1403 patients in 3447 appointments, over a three month period.

Dentists, dental assistants, therapists and hygienists from all over the world volunteer to work on the ship from periods ranging from two weeks to two months. Dentists from Canada, Brazil, America, Europe, India, and Malaysia have all volunteered to work on the hospital ship during its stays in many different countries. During its current trip, the dental team will set up a clinic at the Princess Christian Maternity Hospital in downtown Freetown, and will work together with local staff to treat patients and educate on oral health issues.

New volunteers are always needed to support the outreach expeditions. For more information contact Mercy Ships on 01438727800 or www.mercyships.org.uk.

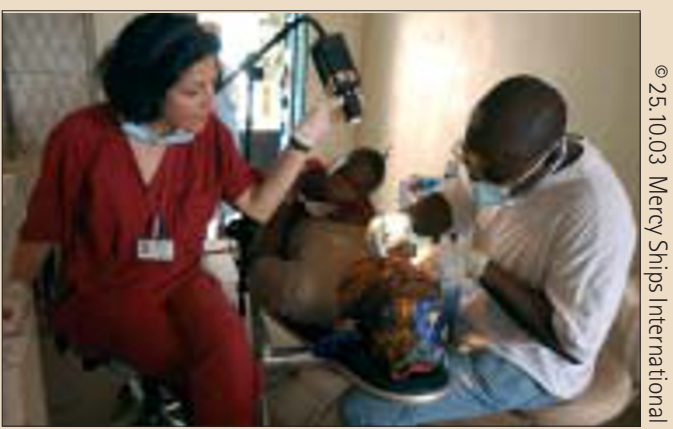

Dental co-ordinator Dominique Vonnez (left) from Switzerland at one of the clinics that treats local people.

\section{CRHP gets new director}

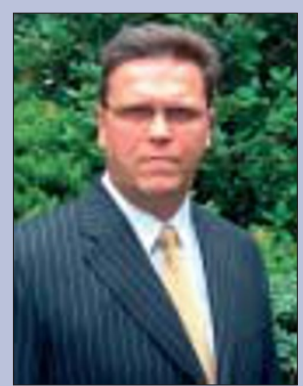

A chief police officer has been appointed director of the newly established Council for the Regulation of Healthcare Professionals (CRHP). Sandy Forrest is currently Her Majesty's Assistant Inspector of Constabulary for Scotland with the rank of Deputy Chief Constable. He will take up his post with the CRHP - an overarching, independent body which oversees the regulatory work of nine organisations including the GDC - later this year. The CRHP has a Council of 19 members, including nominees from each of the regulatory bodies regulating healthcare professionals and ten lay members. 